\title{
Too old to work?
}

\author{
Per Erik Solem \\ NOVA: Norwegian Social Research, Munthesgt. 29, N-0260 Oslo, Norway \\ Telephone +4722541267 Telefax+4722541201 E-mail pes@isaf.no
}

\begin{abstract}
The article reviews Norwegian and international research on aging and work; causes of early exit, attitudes towards older workers, aging and work performance, and trends of changes in working life. Workers seem to have become too old to work at increasingly younger ages. Recent and future demographic changes call for initiatives to keep older workers in the work force. In many countries favourable early retirement arrangements are reversed in order to stop pulling older workers prematurely out of work. The other main group of factors causing early exit, the push factors in the work environment, have until recently attracted less attention. Even if older workers in general seem to be no less effective than younger workers, employers prefer to recruit younger workers, and to dismiss older workers when reducing the staff. However, employers' cognitions of older workes' performance is quite nuanced. There seems to be an emotional ambivalence where negative feelings are less openly expressed, still they seem to have a strong influence on decisions. Ways of influencing attitudes towards older workers are discussed. Companies creating working conditions to stimulate, include and motivate middle-aged and older workers may get an advantage in the market. This may even benefit workers of all ages.
\end{abstract}

\section{EARLY EXIT}

During the last decades, rates of early exit from work have shown a substantial increase in most OECD countries. One could ask if people are becoming too old to work at increasingly younger ages, or if working life is becoming too 'young' for middle-aged and older people.

In Norway the employment rate among men 60-66 years old has decreased from $72 \%$ in 1980 to $52 \%$ in 1995. The last couple of years there has been an increase to 58\% in 1997 (Fig. 1). For women in the same age group the employment rate has been stable around 40\% (Fig. 2, source: Statistics Norway 1980-1997).

Figure 1 shows a steady decrease, until 1996, in employment for the oldest men, while the employment for all men had a small increase in the mid-1980's and started to rise again in 1994. The decrease in employment of older men seems to have been independent of the general employment situation, until 1996. Unemployment has decreased from $6.0 \%$ in 1993 to $4.1 \%$ in 1997 and further to 2.5 percent by March 1998 . With a few years delay, employment among older men has followed the improvement of the general employment situation. All age groups have benefited from the recent improved employment situation, but especially the youngest group (16-24 years). Whether this is going to last is of course difficult to say. For the older group it may be counteracted by the recent (1998) lowering of the pensionable age of the AFP (a negotiated pension system covering $60 \%$ of the work force) to the age of 62 .

Figure 2 shows an increase in employment of women aged 16-74 years, while there are only small changes in employment for older women. The recruitment of younger and middle-aged women has the effect of masking an increasing early exit in employment rates among the older women appearing as stabile. There is a cohort effect of new cohorts reaching the age of 60 with higher employment rate than earlier cohorts of 60 years old women.

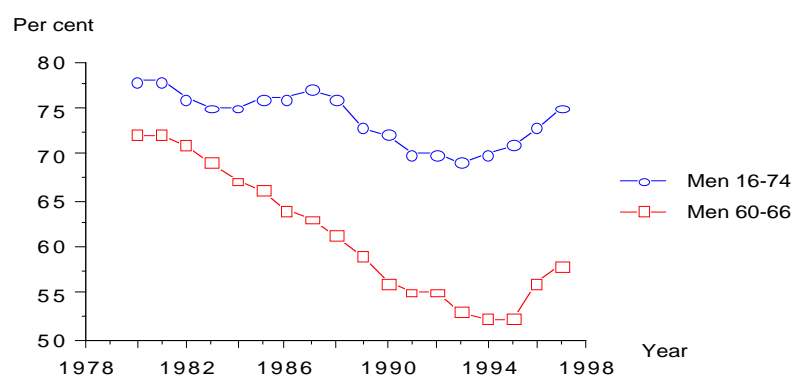

Figure 1. Employment rates for men aged 16-74 years and 60-66 years, 1980-1997.

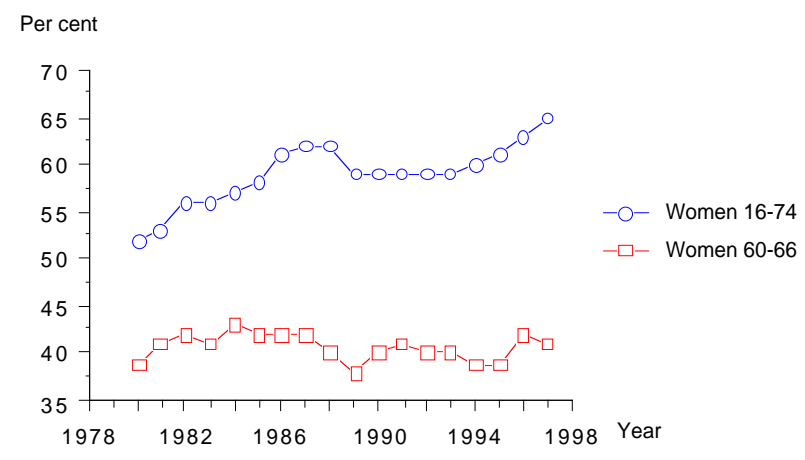

Figure 2. Employment rates for women aged 16-74 years and 60-66 years, 1980-1997. 
Calculations done by Pedersen (1997) indicate that there are only small differences in average age of exit for men and women. For those being employed at the age of 55, both men and women have 64 as the average age of exit, which is a high age of exit compared to other countries. However, such calcualtions are not very comparable. Different methods are used, and in a Norwegian report from 1994 (NOU 1994:2), 61 years was found to be the average. Here disability pension from the age of 16 was included.

The employment situation in the 1990's for older people (55-64 years) is very different between the Nordic countries (Table 1). Iceland has very high employment rates, and there is almost no decrease during the 1990's. On the other extreme is Finland, where only 1 in 5 in the age group 55-64 is employed, and where the decrease has been substantial. Authorities in Finland started in 1998 a five years programme, funded with 25 million FIM, to reintegrate older workers in the workforce.

Table 1. Employment rates in the age group 55-64 in the Nordic countries. 1990 and 1996 (Source: Nordic Statistical Yearbook 1997)

\begin{tabular}{lrrrrr}
\hline & Denmark & Finland & Iceland & Norway & Sweden \\
\hline Men & & & & & \\
1990 & 62 & 42 & $92^{1}$ & 70 & 74 \\
1996 & 55 & 20 & 90 & 67 & 64 \\
Change & -7 & -22 & -2 & -3 & -10 \\
Women & & & & & \\
1990 & 36 & 36 & $77^{1}$ & 52 & 64 \\
1996 & 32 & 19 & 77 & 57 & 59 \\
Change & -4 & -17 & +0 & +5 & -5 \\
\hline 1991 & & & & &
\end{tabular}

Finland shares the situation of extensive early exit with some other European contries, especially France, Austria, the Netherlands and Belgium. One reason is the introduction in the 1970's and 1980's of favourable early exit pension systems, which was a reaction to the employment situation. A special aim of such systems was to decrease unemployment among young people. However, the systems did not give the intended effect, and most of them are now reversed, also because the Economic and Monetary Union requires cuts in public expenditure. But at the same time there is a growing awareness in Europe that due to demographic changes the older part of the workforce will be increasingly needed. There is also a growing awareness that working life needs the qualities of older workers, like stability, dependability and expertise. At times of great changes older workers may represent a continuity that companies may benefit from, even if this might not be measureable in individual productivity.

\section{DEMOGRAPHIC CHANGES}

Future increases in the number of old people (above 80 and 90) is well known. In gerontology, population changes in younger age groups are not so often paid attention to. In figure 3 the age changes over the next decade is illustrated for Norway. Young people 20-34 years of age is expected to decrease in numbers by 129.000 or $13 \%$ (from 990.000 to 861.000 ), while the older group 50-69 will increase by 293.000 or $36 \%$ (from 808.000 to 1.101.000) (NOS C 414).

'The impact on population aging on employment and the labour market is one of the most important issues confronting all European societies' (Walker 1997: 123). The challenge is to recruit those above 50 and 60 back to work, or rather to prevent early retirement.

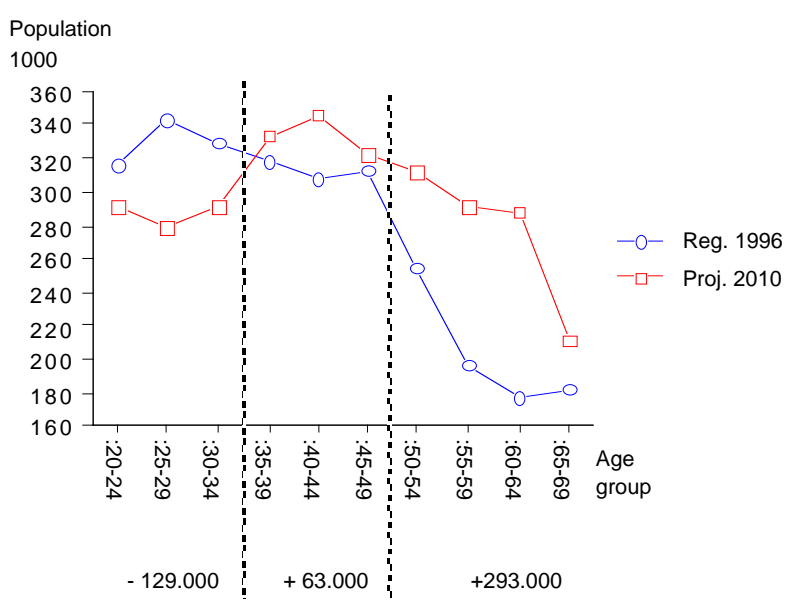

Figure 3. Population in Norway 20-69 years grouped by age. Registered 1996 and projected to 2010 (alternative M).

\section{CAUSES OF EARLY EXIT}

As we have seen for Norway, employment rates decreased steadily during the 1980 's through the first half of the 1990's. This happend quite independent of changes in general employment and unemployment rates. And the decrease in employment rates among older men started many years ahead of the rise in unemployment during the 1980 's. In other countries early exit may be more closely connected to increasing unemployment, especially when systems of early exit pensions are introduced as reflections of the unemployment situation.

Another cause of early exit may be structural changes in the labour market. During the last decades there has been a shift from traditional manufacturing industries towards service industries, including public services like care of the elderly. This implies a shift from male to female dominated industries, whereby older men has left the labour force while young and middle aged women have entered.

Shifting focus from such structural causes to the perspective of the individual workers, there are obviously a range of different wishes. Some older workers prefer early retirement, others wish to continue beyond normal pensionable age, while still others would like to have a period with both; part time work and partial pension. It is difficult to establish the size of those groups. Wishes will vary according to both working 
conditions, health, pension benefits, family situation, leisure interests, and in general, what the realistic options are. However, when people retire early, this seems in general to be in accordance with the expressed wishes of the retirees (Halvorsen \& Johannesen 1991, Rix 1994). But some have mixed feelings and change preference when the moment of exit approaches. During the last years ahead of retirement age most people look forward to quit working, but some months or up to a couple of years before 'the moment of truth', quite a few seem to change position and wish to continue working (Solem 1989).

Public arrangements for early exit, that is before the age of 67 , has been relatively sparse in Norway. The negotiated early pension (AFP) was introduced only in 1989, and has gradually lowered the pensionable age to 62 from 1998 on. A white paper from 1994 (NOU 1994:2) concluded that rather than lowering pensionable age we should stimulate employment among older persons. To achieve this, the paper recommends to make pension benefits less attractive. It is also recommended to improve personnel policies, working conditions, and training for employees in general, but also focusing on older workers.

This exemplifies the two main models of explaining early exit; 'pull' or the attraction model, and 'push' or the expulsion model. Push factors are related to work; poor working environment, structural unemployment, increasing demands and stress, negative attitudes towards older workers, and informal expectations from fellow workers that one should retire as soon as the option is available. These are factors pushing workers out. Pull factors are located in life outside work, like favourable pension systems that are pulling workers out.

Research on early retirement have not been able to give any definite answer concerning the relative importance of the two models (Dahl \& Midtsundstad 1994, Kilbom \& Westerholm 1996, Kolberg 1991, Lahn 1996, Solem \& Mykletun 1996). Pedersen (1997) found on hypothetical questions that fairly equally sized groups (20-30\%) agreed on the one side that improved working conditions would make them postpone retirement, and on the other side that they would postpone retirement if that resulted in a higher pension. This indicates that it is possible to influence the time of retirement by factors both in the working environment and in the pension system.

In additon to age, naturally poor health and jobs with high health risks, predict early exit. In a longitudinal study over eleven years Solem \& Mykletun (1996) found reduced work ability due to disease, high age, low education, and collaboration with colleagues more than half the day, to be the strongest predictors of early exit. Other significant work environment predictors were poor climatic conditions, little variation in tasks and rare exposure to hectic and stressful work. Early exit might be counteracted by including older workers more in the daily challenges at the work place and in training activities. In the next paragraph we shall discuss another factor; employers' attitudes towards older workers.

\section{ATTITUDES TOWARDS OLDER WORKERS}

It is difficult to establish how common negative attitudes towards older workers are, and to what extent age discrimination is present in recruitment, training and promotion. There is a lot of anecdotal material on age discrimination, and older workers obviously have greater problems finding new jobs. However, not only older persons are of the opinion that age discrimination is a problem. A survey in the (at that time) $12 \mathrm{EU}$ countries (Eurobarometer) found that such opinions were just as common in younger age groups (Walker 1993). A majority of the EU population agreed that older workers were discriminated against regarding recruitment (79\%), training (67\%) and promotion (62\%). The majority was clear in all countries, in all age groups and both among men and women. Also a majority (except in Denmark) supported legislation against age discrimination in working life. USA has had such legislation (The Age Discrimination in Employment Act) since 1967, however without any obvious success in getting rid of such discrimination (Rix 1994).

Studies on employers' attitudes towards older workers support the impression from the EU public opinion poll that age discrimination is a problem. In a Norwegian study a random sample of 1284 employers were asked who they would prefer for recruitment; an unemployed person under 25 years of age, an unemployed above 60 years, a long term unemployed, a person under rehabilitation, or a refugee (Hardoy 1993). The question was posed as a case were the employer was about to hire a worker for a simple routine job. All the five applicants had completed primary school, but not any further education. The majority of the employers $(61 \%)$ ranked the young person as the most preferred, and 54\% ranked the old one as number four or five. Thus, even compared to other groups with a marginal position at the labour market, older workers (above 60) are less attractive for recruitment.

Another study illustrates that ageism may operate far below the age of 60. Larsen (1991) sent questionnaires to the companies advertising vacancies in Norway during a few months in $1988 / 89$. The 2500 vacancies that was filled within two months were analysed. $56 \%$ of the jobs $(67 \%$ in the private sector and $48 \%$ in the public sector) were considered to be performed better by workers below 35 . When it came to appointment an even larger proportion actually hired workers below $35 ; 74 \%$ in the private sector and $60 \%$ in the public sector. However, the age distribution of applicants was not known.

In a smaller, qualitiative study Waldrop (1992) interviewed personnel managers, union leaders and workers in 13 Norwegian companies. Among the personnel managers she found a mental disposition to 
connect elder workers with retirement. Their associations to 'older workers' were not training, job redesign, or productivity, but retirement. This may predispose for exclusion rather than inclusion of older workers. However, their evaluation of older workers was not only negative. Most managers did mention strong sides as experience, dependability and low absentism, and they did not generally judge older workers as incompetent for jobs demanding creativity. Some preferred older workers to younger ones, as is also reported by others (Laczko 1990). But the majority was inclined to exclude older workers from the labour force, often with reference to unemployment among young persons. Concern for unemployed young workers was also expressed by union leaders and even by older workers themselves, as a reason to accept retirement.

It is worth noting that the same argument has been used also at times with low unemployment. In a study from 1973-75 older workers reported that they felt a pressure both from managers and fellow workers that they ought to retire as soon as pension rules allowed them to, because of youth unemployment (Daatland 1979). At that time unemployment rates were around $1 \%$, what we today would call full employment. This alludes to a hypothesis that acceptable arguments (concern for unemployed young people) are stretched very far to hide reluctance to recruit older workers. It may be difficult to tell a loyal old worker that he should retire because he is not considered to be productive enough. It may be easier to appeal to a agreed upon social responsibility for the welfare of young people.

Faced with older workers, negative attitudes are often not openly expressed. Such attitudes include poor trainability, resistance against change, less creativity, lower productivity, and unwillingness to take economic risks (Davies et al. 1991). The prevalence of negative attitudes is, as mentioned already, difficult to establish. Results differ, and in some studies older workers are in general not considered to be less productive than younger (WHO 1993). This is surprising, considering the low demand for older workers. One reason for this appearant discrepancy between attitudes and behavior may be that it is the top managers who have the most positive attitudes, while line managers, with more direct recruitment responsibility, are more negative (Taylor \& Walker 1994).

Most often, evaluations of older workers are, as expressed to a researcher, characterized by both positive and negative views. Taylor \& Walker (1994) found that in about 300 English companies the amount of negative and positive came out as fairly equal, but slightly more positive. However, on the more practical level the negative predominated, since the employers wanted primarily to get rid of the older workers when it came to downsizing.

Twenty-three managers from eight Norwegian companies were on the whole negative towards older workers' flexibility and ability to change (Jenssen 1994). Older workers' experiences were viewed more positively, but quite a few also saw negative aspects with having long experience, they found experience aquired at the age of 30 to 40 to be sufficient. These attitudes were connected to a recruitment policy were workers below 50 were preferred, and some companies put the age limit for recruitment at 30 to 35 years. In the same study Jenssen interviewed 10 personnel consultants recruiting employees for companies. They expressed more nuanced views on older workers, and was of the opinion that chronological age is quite irrelevant for individual work ability. To the extent that older workers were less productive they connected it less to age than to adverse working conditions and organisational structures inhibiting growth. But the consultants were not very often heard by their employers who most often had set an age limit in advance.

It seems to be different views at the different levels in the recruitment procedure, what we could call an organisational ambivalence. Such ambivalence may also be traced at the individual level. The attitudes expressed and the actions performed are not always in agreement. In an American study students of economy rated older workers to have as good work ability as younger ones. They nevertheless would recommend the younger ones for recruitment (Davies et al. 1991). In another study managers agreed that older workers are discriminated at the labour market, but not in the manager's own company (Stagner 1985). This alludes to unacknowledged negative attitudes and emotional ambivalence having an influence on behavior. If this is true, it may be difficult to change negative attitudes towards older workers by pointing to their strong sides. Most employers would agree in the strong sides, but nevertheless be inclined to exclude older workers.

The three elements of attitudes; cognitions, emotions and behavior dispositions are connected, but not necessarily in agreement. It is possible to think that older workers are as productive as younger ones (the cognitive element), and at the same time to dislike to recruit older workers (the emotional element). Often the emotional element is more vague and less explicitly formulated, and it may be suppressed in order to support a self-image of being a rational person. Anyway, emotions may, without our awareness, well influence behavior. Negative emotions may overshadow positive thinking, and they are not easy targets for rational arguments.

Actions trying to change behavior towards older workers should not focus too much on cognitions about the work ability of older workers, but should include broader information, for instance about the benefits of a heterogenous age composition of the labour force, demographic changes demanding greater use of older workers, and that investments in education of older workers may give greater returns, since they tend to be more loyal and stable (Warr 1994). But in order to counteract effects of negative attitudes, it is crucial to look at the emotional elements of such attitudes. 


\section{CONTAGION FROM ATTITUDES TOWARDS OLD AGE?}

One basis for negative attitudes towards older workers might be found in more general attitudes towards aging and old age, in the fear of growing old and infirm, and in the fear of dying. These are anxieties for matters usually occuring outside working age, but we get reminders of the aging process much earlier. Reminders as wrinkles and reduced vitality/virility are big business for cosmetics and pharmaceutical industries. Older workers may also represent such reminders we may want to hide. If there is some truth in this hypothesis of contagion from attitudes towards old age and dying, openness and acceptance of the natural process of aging and dying may be of benefit even for older workers.

Such thinking may seem to be a little far out when talking about managers in their 40's and 50's being reluctant to recruit workers in their 30's because they are too old. However, the counterpart of fear of aging is the glorification of youth.

Even if there is fear of aging, attitudes towards the elderly are complex. Cognitions about aging and old age tends to be skewed towards the negative. Older people are seen as more frail, more in need of help, and more often institutionalised than in reality (Tornstam 1986). On the other hand feelings towards the elderly are positive in the way that most people are giving older people high priority in the distribution of welfare resources (Tornstam 1986, Martinussen 1992). This positive element seems closely connected to the exaggerated negative cognitions. The feelings seem to have a strong flavour of compassion and pitying. Such feelings may predispose for patronising behavior towards old people.

In the public debate old people are conceived as a social problem and a burden associated with the threatening metaphor; 'the age wave'. At the same time the social definition of 'elderly' is creeping down the age scale. Around 1970, when the normal pensionable age was 70 years, the 'elderly' was on the average conceived as those above 70, while this average two decades later was 64 (Daatland 1994). This change in the social definition of 'elderly' is not caused by an increased infirmity in the actual age group, since rather the opposite has taken place. Probably the defintion of old age has followed the increasingly early retirement from work. Working life seems crucial in the definition of old age.

The social definition of 'elderly' does not, as an average, include the older part of the labour force. But there is some overlap and no firm and rigid border between the working and the elderly. Studies indicate that older workers are given less challenging jobs and often left more or less alone with their old tasks and protected from daily hassles and new demands (Schooler 1987, Solem \& Mykletun 1996, Lahn 1996).

\section{VARIABILITY IN THE AGEING PROCESS}

Attitudes towards older workers have elements of stereotypes about the aging process. The concept of aging seems to be primarily connected to aging of the body. According to a biological model of aging there is growth until the person is grown up and reaches a stage of maturity, whereafter there is a gradual and accelerating decline until death. This model is unidimensional and fatalistic. Aging is defined as decline. Even for biological aging this is somewhat too simple (Kirk 1997). For psychological and social aging it is inadequate. Aging is changing. It is not only irreversible decline, but changes in both positive and negative directions. Age changes emerge throughout the life course as a result of interaction between the individual and the environment or in other words; through transactions between changing indiviuals and changing environments (Featherman et al. 1990). This opens for great variablity in the aging process. Variability comes partly from genetic differences (primary aging) and partly from differences in living conditions, including working conditions (secondary aging).

In addition to a great variability in the aging process, quite a few other things than aging, for instance health, motivation, interests, actual working conditions, training, attitudes from employers, fellow workers, family, friends and the community as a whole, will influence the work ability of older workers.

However, sooner or later there is decline in aging. First the maximum capacities decline. A marathon runner taking out his maximum capacity will reach top performance in his 30's. But workers seldom need their maximum capacity to perform well at work. Even in heavy physical work one may perform as well as before up in high ages by working closer up to the maximum.

One strategy to overcome negative effects of decline is to compensate by using other, better preserved abilities, technical aids or improved ergonomics. This is part of the theory of successful aging called: 'Selective optimalization with compensation' (Baltes \& Baltes 1990). The idea is that when capacities decline, one may select to optimalize, preserve or use closer up to maximum the capacities needed in order to stay active in the life areas one is most interested in and selects. If that is insufficient, one may find ways to compensate for the decline.

However, as we have said already, age changes are not exclusively characterized by decline. When the changes are characterized by growth and development, compensation is irrelevant. Some abilities will when they develop, displace other abilities. For example, when children aquire the capacity for abstract formal thinking, their ability for concrete detailed memory is weakened (Labouvie-Vief 1982). When a new and more advanced ability is replacing a less advanced ability, it is of no meaning to talk about compensation. 
Such things happen throughout life. In old age, wisdom is a good example. The concept of wisdom implies a continously growing mental capacity (Sternberg 1990). Confronted with a problem, older people will draw more on their experiences, while younger ones will draw more on their ability of formal logical thinking. It depends upon the situation and the problem which approach is the more successful. With rich experience one may realize more of the complexities of a situation, and may need more time to sort everything out, before a decision is reached. However, it is also claimed that older managers are quicker to reach decisions because they have aquired an experience based intuition saving them from time consuming theoretical and logical reasoning. In wisdom there are many elements, such as broad-mindedness, flexibility, tolerance for differences, self-understanding and rich knowledge about facts and procedures. Wisdom is not automatically a result of aging per se. Not every old person is wise. But rich experiences is a prerequisite for the growth of wisdom. By closing oneself up, or being closed up by others for instance at the job, in habitual ways of thinking and doing things, and by not seeking or not getting new challenges and new experiences, one may avoid the growth of wisdom.

A ten-year longitudinal study showed that jobs demanding flexible thinking and autonomous judgements, increased the workers' mental flexibilty and autonomy. Likewise, routine jobs with little autonomy resulted in decline of the workers' mental flexibility, and increased conformity (Schooler 1987). When mental capacities decline with age, this may be related to the work situation becoming less complex and less challenging as the worker ages. Schooler (1987) refers studies from USA and Poland showing that the jobs older workers do often are less complex, less demanding and less stimulating. When judging the work ability of older workers it is important to take both the actual work situation and the individual work history into consideration. Poor performance may just as well result from an old job as from an old worker.

\section{AGING AND WORK ABILITY}

Based upon a review of more than 100 studies, Warr (1994) concludes that on the average, older workers are no less effective than younger ones. However, there are wide individual variations and wide variations between jobs. In jobs requiring physical strength, endurance and fast reactions, peak productivity is in most studies found in the 30's and 40's (WHO 1993). At the same time some workers in their 50's are performing better than most workers in their 20's. Among white collar workers studies are often showing no clear age differences, while some, like proofreaders and sales representatives are found to be best when they are old (Stagner 1985, Davies et al. 1991).

On the individual level, age is no good predictor of work ability. Even if there is some decline with age, particularly in maximum performance, this cannot be easily translated to performance at a job. In a study by Salthouse (1984), older typists were slower in laboratory tests on tapping speed, but performed as well as younger typists in typing work. This may be explained by the compensation hypothesis in the way that they compensated their slower tapping with more economical reading of the manuscript. Or it may be understood as the result of emerged abilities in reading replacing tapping ability, and if so, it is more a question of growth than of compensation.

In a Swedish study of technical control work no age differences were found in the number of defects discovered. But there were great individual differences unrelated to age. The management wanted to reduce those differences to achieve a more standardized control, treating customers on more equal terms. In follow-up three years later the individual differences had decreased, particularly among the older (above 55 years) controllers. The older controllers changed their performance more in direction of the wanted average (Hallsten \& Solem 1996). This may indicate greater loyalty to the aims of the company, and that older workers are no less flexible in changing behavior.

In general, older workers are able to perform quite as well as younger ones. Some improve their performance with age, others decline. Often it is possible to compensate for age decline, for instance with adaptations of the working conditions. But in some jobs even small declines may have great negative consequences, for instance among pilots, police, and fire fighters. However, the risk of acute illness endangering the security of colleagues and the public is very small. In a scientific report to the American Congress the risk is calculated to about one case every 25 years in a police force of 500, and it is more dependent upon health than upon age (Productive Aging News 1992). Studies of accidents among air craft pilots has shown that the older pilots are less accident prone than younger ones, even up to the age of 70 . Frequent health controls seems to be more preventive than a low retirement age (Productive Aging News 1993).

\section{WORKING LIFE IS CHANGING}

One trend in working life is that the border between work and leisure is weakened. Companies organise leisure activities, holiday travels, housekeeping, babysitters, and care for older parents. In this way they compete for the most attractive labour force, and they may use the staff in a more flexible way when their family obligations are taken care of. Another trend is that companies increase their flexibility by employing a smaller permanent staff and use more short term employees, project staff, contracts with self-employed workers, or outsourcing. This has a parallell in the so called 'just in time logistics', where companies minimize their stocks and move parts, raw materials, and products out on the highway, wherefrom they arrive 
just when needed. In the same way more workers may be moved 'out on the street' to be called upon just when needed.

By these trends the gaps between A-, B-, and Cteams in working life may increase. The A-team is the most attractive, and is offered generous welfare arrangements and fringe benefits, in addition to high pay. The B-team is called upon for short term employment when needed, while the C-team is basically outside working life and has to depend upon public welfare, insurance or family to secure their income. They may have occasional small or part-time jobs. Some of them are included in the employment statistics, since the definition of gainfully employed is: 'at least one hour of paid work last week, or temporarily absent from work last week'.

It is not obvious how these trends may influence the situation for older workers. Demographic changes with fewer young persons to recruit, may open up for more older workers in the A-team, and for early retirees on the B-team, combining part time work and partial pension. The metaphore of A-, B-, and C-teams alludes to sports competitions, and illustrates the increasing global competition in working life. An Ateam of 'winners' and able substitutes from the B-team are beneficial for companies. The 'losers' belong to the C-team. Attitudes towards older workers indicate that in the present situation one doesn't need to be very old to be a candidate for the C-team.

The mentioned trends in working life increase flexiblity for employers. Even for employees flexibility has increased. The age-segregated life-course is softened-up. Students more often have part time jobs than some years ago. The rights to take leaves at childbirth and for child-care are more generous, and there are some possibilities for combination of part time work and partial pension, however, not yet widely used. Information technology opens up options for work at home in the family/leisure arena. Life-course flexibility in combination of work, education and leisure has been proposed, for instance by Gösta Rehn already in 1972, a proposal he reintroduced in 1990 (Rehn 1990). The Norwegian committee on working hours reforms proposed reforms in the same line in 1987 (NOU 1987:9A). Today 'time accounts' is discussed, and already implemented on a small scale. A reform of further education is planned, giving workers the right to leaves for further education. Such flexibili- ties may improve the possibilities for older workers to remain employed up to high ages. Or like a 60-yearold industrial worker said in an interview:

'I think we should retire when in the 50's. Then we could have 10-15 good years as retirees while we still were in good health and had the energy to pursue our favourite leisure activities. Then we could re-enter working life when approaching 70' (Daatland \& Solem 1995). This might be a future option.

\section{CONCLUDING REMARKS}

In European public opinion polls, a majority agrees that older workers are discriminiated in working life and that it should be introduced legislation against it. Employers prefer to recruit younger workers, and to dismiss older workers when reducing the staff. However, their cognitions of older workes' performance is quite nuanced with both postive and negative opinions. There seems to be an emotional ambivalence where negative feelings are less openly expressed, still they seem to have a strong influence on decicions.

On this background it may be difficult to change attitudes by arguing against negative cognitions. It may be better to adress other factors, such as demographic changes resulting in a need to depend more on older workers, and the benefits of an age heterogenous labour force. In times of change, it may be beneficial to have various experiences represented in the labour force. It may also help to inform about what aging is and is not, and in that way counteract rigid conceptions of general and irreversible decline as firmly connected to chronological age. However, it is unlikely that fundamental changes in attitudes will take place unless the emotional elements of attitudes are touched. Negative attitudes towards older workers may be nourished by general cultural attitudes towards aging, old age and death. More openness around these natural parts of life may even contribute to more realistic conceptions of older workers.

In conclusion, companies putting away their ageist behavior, creating working conditions to stimulate, include and motivate middle-aged and older workers, may get an advantage in the hardening competition. This may benefit workers of all ages. More equal distribution of work between the age groups may reduce pressure on the young, and open up for reforms like shorter daily working hours and longer holidays.

\section{REFERENCES}

Baltes PB, Baltes MM. Psychological perspectives on successful aging: The model of selective optimization with compensation. In: Baltes PB, Baltes MM (eds.). Successful aging. Perspectives from the behavioral sciences. Cambridge: Cambridge University Press, 1990: 1-34.

Dahl E, Midtsundstad T. Hvorfor går eldre arbeidstakere av før ordinær pensjonsalder: vil de, eller må de? In: NOU 1994:2, Fra arbeid til pensjon:. Oslo: Statens forvaltningstjeneste, 1994: 310-334.

Davies DR, Matthews G, Wong CSK. Aging and work. Int Rev Ind Org Psychol 1991; 6:149-211.

Daatland SO. Fleksibel pensjonsovergang i store industribedrifter. NGI rapport nr. 1-1979. Oslo: Norsk gerontologisk institutt, 1979. 
Daatland SO. En ny fase av livet. Aldring \& Eldre 1994; 11 (1): 21.

Daatland SO, Solem E. Velferdsgevinst eller velferdstap å bli pensjonist? In: Kjønstad A, Hatland A, Halvorsen B (eds.). Det norske trygdesystemet. Fortid, nåtid og framtid: Oslo: Ad Notam Gyldendal, 1995: 85-112.

Featherman DL, Smith J, Peterson JG. Successful aging in a post-retired society. In: Baltes PB, Baltes MM, (eds.). Successful aging. Perspectives from the behavioral sciences. Cambridge: Cambridge University Press, 1990: 50-93.

Hallsten L, Solem PE. Ålder och arbetsprestation. In: Aronsson G, Kilbom Å (eds.). Arbete efter 45. Solna: Arbetslivsintstitutet, 1996: 173-184.

Halvorsen K, Johannesen A. Når bedriften ikke har bruk for deg lenger. NKSH-rapport nr. 91:2. Oslo: Norges kommunal- og sosialhøgskole, 1991.

Hardoy I. Hvem foretrekker arbeidsgiverne å rekruttere? Søkelys på arbeidsmarkedet, 1993; 10 (2): 101-106.

Jenssen EW. Eldre arbeidstakere - ofre for selvoppfyllende profetier i arbeidslivet? Hovedoppgave ved Psykologisk institutt, Universitetet i Oslo, 1994.

Kilbom Å, Westerholm P. Sannolikheten för äldre att arbeta fram till pensionen. In: Aronsson G, Kilbom Å (eds.). Arbete efter 45. Solna: Arbetslivsintstitutet, 1996: 85-101.

Kirk H. Gerontologiens farlige kurver. Gerontologi og samfund 1997; 13 (4): 82-84.

Kolberg JE. En empirisk utprøving av utstøtingsmodellen. In: Hatland A (ed.). Trygd som fortjent? En antologi om trygd og velferdsstat. Oslo: Ad Notam, 1991: 91-116.

Labouvie-Vief G. Growth and aging in life-span perspective. Human Development 1982; 25: 65-79, 84-88.

Laczko F. Early exit and the employment of older workers in the 1990s in the United Kingdom. In: Habib J, Nusberg C (eds.). Rethinking worklife options for older persons. Washington, D.C.: International Federation on Aging, 1990: 9-24.

Lahn LC. Aldring og arbeidsmiljø. Notat 4/96. Oslo: Arbeidsforskningsinstituttet, 1996.

Larsen KA. Fremtidens arbeidsmarked. Oslo: ECON Senter for økonomisk analyse Report no. 19/91, 1991.

Martinussen W. Solidaritetens grenser: Økt generasjonsstrid om godene? In: Daatland SO, Solem PE (eds.). $O g$ du skal lenge leve i landet. Dilemmaer og veivalg i eldrepolitikken. Oslo: Universitetsforlaget, 1992: 197-207.

Nordic Statistical Yearbook 1997. Copenhagen: Nordic Council of Ministers, 1997.

NOS C 414. Framskrivning av folkemengden 1996-2050. Oslo: Statistisk sentralbyrå, 1997.

NOU 1987:9A. Arbeidstidsreformer. Oslo: Universitetsforlaget, 1987.

NOU 1994:2. Fra arbeid til pensjon. Oslo: Statens forvaltningstjeneste, 1994.

Pedersen AW. Mellom arbeid og pensjon. Oslo: Forskningsstiftelsen FAFO Report no. 223, 1997.

Productive Aging News, No. 68. New York: Mount Sinai Medical Center, 1992.

Productive Aging News, No.71. New York: Mount Sinai Medical Center, 1993.

Rehn G. (1990) Flexibility and free choice in working life. In: Habib J, Nusberg C (eds.). Rethinking worklife options for older persons. Washington, D.C.: International Federation on Aging, 1990: 199-215.

Rix S. Reflections on aging productively. Aging Int 1994; 21 (2): 63-66.

Salthouse TA. Effects of age and skill in typing. J Exp Psychol 1984; 13 (3): 345-371.

Schooler C. Psychological effects of complex environments during the life span: A review and theory. In: Schooler C, Schaie KW (eds.). Cognitive funtioning and social structure over the life course. Norwood, NJ: Ablex, 1987: 24-49.

Solem PE. Enighet og tvisyn. Om yrkesaktives holdninger til øvre aldersgrenser $i$ arbeidslivet. NGI rapport nr. 31989. Oslo: Norsk gerontologisk institutt, 1989.

Solem PE, Mykletun R. Arbeidsmiljø og yrkesavgang. NGI rapport nr. 2-1996. Oslo: Norsk gerontologisk institutt, 1996.

Stagner R. Aging in industry. In: Birren JE, Schaie KW (eds.). Handbook of the psychology of aging: New York: Van Nostrand Reinhold, 1985: 798-817.

Sternberg RJ. Wisdom. Its nature, origins and development. Cambridge: Cambridge University Press, 1990.

Taylor P, Walker A. The ageing workforce: Employers' attitudes towards older people. Work Employm Soc 1994; 8 (4): 569-591.

Tornstam L. Aldrandets socialpsykologi. Stockholm: Rabén \& Sjögren, 1986.

Waldrop A. Før vi vet ordet av det. En analyse av personalpolitiske tiltak for eldre arbeidstakere. Oslo: Forskningsstiftelsen FAFO Report no. 133, 1992.

Walker A. Age and attitudes. Main results from a Eurobarometer survey. Brussels: The EU Commision, 1993.

Walker A. Combating age barriers in employment. Dublin: European Foundation for the Improvement of Living and Working Conditions, 1997.

Warr P. Age and job performance. In: Snel J, Cremer R (eds.). Work and Aging: A European Perspective. London: Taylor \& Francis, 1994: 309-322.

WHO. Aging and working capacity. Geneva: World Health Organization Technical Report Series 835, 1993. 